\title{
Identification of Beche-de-mers from Indonesia by molecular approach
}

\author{
GINTUNG PATANTIS", ARIYANTI S. DEWI, YUSRO N. FAWZYA, MUHAMMAD NURSID \\ Research Center for Marine and Fisheries Product Processing and Biotechnology. Jl. KS Tubun Petamburan VI, Jakarta 10260, Indonesia. \\ Tel./fax.: +62-21-53650158, `email: gintungpatantis@gmail.com
}

Manuscript received: 29 November 2018. Revision accepted: 29 January 2019.

\begin{abstract}
Patantis G, Dewi AS, Fawzya YN, Nursid M. 2019. Identification of Beche-de-mers from Indonesia by molecular approach. Biodiversitas 20: 537-543. Sea cucumbers have been commercially traded around the world due to their nutritional values and health benefits. Sea cucumbers are marketed as processed sea cucumber, also known as beche de mer, teripang, haisen or gamat. Due to the high global demand of beche-de-mers, there have been several cases of fraud due to the visual shape and color similarities of processed sea cucumbers. Additionally, the local name diversity of Indonesian sea cucumbers making the identification of beche-de-mers difficult. Therefore, this study aimed to identify commercial sea cucumbers from selected locations in Indonesia by molecular approach. The targeted Cytochrome c oxidase subunit I (COI) was used in this research. A total of 25 beche-de-mers was purchased from local markets in Indonesia, i.e. Boalemo (17 local names), Pesawaran (5), Surabaya (2) and West Lombok (1). Results showed that 22 species of beche-de-mer were successfully identified, ie. Acaudina sp., Actinopyga echinites, A. lecanora, A. miliaris, Bohadschia argus, B. marmorata, B. ocellata, B. vitiensis, Holothuria sp. H. atra, H. coluber, H. edulis, H. excellens, H. fuscocinerea, H. fuscogilva, H. fuscopunctata, H. scabra, Pearsonothuria graeffei, Phyrella sp., Stichopus herrmanni, S. horrens and S. monotuberculatus. The identification of Indonesian beche-de-mers using molecular method could support the identification of the local sea cucumbers to overcome mislabeled and fraud. Correct identification is important for the record of beche-de-mer trade in Indonesia and further conservation management
\end{abstract}

Keywords: Beche-de-mer, Indonesia, molecular identification, sea cucumbers

\section{INTRODUCTION}

Sea cucumbers have been commercially used and traded as beche-de-mer, gamat, teripang or haishen for more than 1000 years (Hamel Jean-François et al. 2001) in more than 70 countries (Purcell et al. 2012). Beche-de-mers are widely consumed in Asia region as a delicacy and a traditional medicine because of their nutritional and health values (Hamel Jean-François et al. 2001). They are more than 60 sea cucumber species have been internationally marketed (Purcell et al. 2012). Indonesia, one of the biggest producer, has contributed 26 species of beche-de-mers (Purwati 2005) or even more (Choo 2008) in the international trade. However, the statistics recorded that Indonesian beche-de-mers exports only labeled as teripang, regardless the species. In addition, the local name of each teripang is varied in each region (Setyastuti and Purwati 2015) thus mislabel is common. This condition is difficult for conservation management as many of the sea cucumbers species are overfished. Therefore, it is important to identify and classify the species of the bechede-mers from Indonesia with high-reliability result.

Identification of Indonesian sea cucumbers has been mostly performed using morphological rather than molecular method. Massin (1999) collected and morphologically identified 56 species from Spermonde archipelago; meanwhile, Purwati et al. (2010) identified 18 species from Karimunjawa Island. Other studies were conducted by Supono et al. (2014) from Lembeh Strait (22 species) and Afrely et al. (2015) from Alas Purwo National Park ( 8 species). All of them were identified from fresh sea cucumbers. Furthermore, Setyastuti and Purwati (2015) identified 54 Indonesian sea cucumbers in fresh, salted and dried forms. However, only 33 species were taxonomically confirmed, whereas 21 species of them could not be identified by this method. Some of the dried and salted beche-de-mers were difficult to identify due to shape similarity and ossicle damage.

Other research groups have identified Indonesian fresh sea cucumbers using a molecular method by employing the cytochrome c oxidase subunit I (COI) region. Madduppa et al. (2017) identified seven species of sea cucumbers from Kepulauan Seribu, meanwhile (Amin et al. 2016) identified one species of sea cucumber from Surabaya. The advantage of using COI over the regular method is its resistance to the degradation from heat treatment (Rasmussen and Morrissey 2008). Identification using COI region also have been applied to identify plant and animal species as ingredients in food products (Peres et al. 2007). The same technique has also been used to differentiate seafood products, i.e., fish (Di Pinto et al. 2015; Md-Zain et al. 2018), shrimp (Fernandes et al. 2017) and beche-demer (Uthicke et al. 2010). Based on these reasons, this study aimed to identify beche-de-mers from several regions in Indonesia using the mitochondrial COI genes. 


\section{MATERIALS AND METHODS}

\section{Samples collection}

The beche-de-mer samples were collected from various local markets in Indonesia, such as at Boalemo District, Gorontalo; Pesawaran District, Lampung; Surabaya City, East Java and West Lombok, West Nusa Tenggara between April-July 2018. A total of 47 dried-salted specimens from 25 samples with different local names were obtained.

\section{DNA extraction and amplification}

DNA of each beche-de-mer sample was isolated using the DNeasy Blood and Tissue Kit (Qiagen, Netherlands) based on the manufacturer protocol with slight modification. Approximately $30-50 \mathrm{mg}$ of sample was cut and ground using pestle homogenizer in $180 \mu \mathrm{L}$ lysis buffer (buffer ATL), prior to overnight incubation at $56^{\circ} \mathrm{C}$. The region of COI was amplified using polymerase chain reaction (PCR) by using CO1eF: 5' ATAATGATAGGAGGRTTTGG-3' and COIeR: ${ }^{\prime}$ 'GCTCGTGTRTCTACRTCCAT-3' primers (Arndt et al. 1996). The PCR was conducted using a KOD FX Neo master mix (Toyobo, Japan) that was composed of $12.5 \mu \mathrm{L}$ of $2 \mathrm{x}$ PCR buffer, $5 \mu \mathrm{L}$ of $2 \mathrm{mM}$ dNTPs, $1 \mu \mathrm{L}$ of $10 \mathrm{mM}$ each primer, $1 \mu \mathrm{L}$ of template DNA, $0.5 \mu \mathrm{L}$ of $1 \mathrm{U} / \mu \mathrm{L}$ KOD FX Neo tag and $5 \mu \mathrm{L}$ PCR grade water. The PCR was performed in TProfessional Basic Thermocycler (Biometra, Germany) at the following conditions: initial denaturation at $98^{\circ} \mathrm{C}$ for $2 \mathrm{~min}, 30$ cycles of denaturation at $98^{\circ} \mathrm{C}$ for $30 \mathrm{~s}$, primer annealing at $50^{\circ} \mathrm{C}$ for $30 \mathrm{~s}$, extension at $72^{\circ} \mathrm{C}$ for $1 \mathrm{~min}$, and a final extension at $72^{\circ} \mathrm{C}$ for $7 \mathrm{~min}$. The PCR products ( +675 base pairs) were visualized by agarose gel electrophoresis. The PCR products then were sequenced at 1st Base Laboratories (Malaysia).

\section{Sequence data analysis and phylogenetic tree}

The COI Sequences data from forward and reverse were combined using MEGA 7 (Kumar et al. 2016). The combined sequences then compared to those of references in the database by aligning the sequences using Basic Local Alignment Search Tool (BLAST) (Altschul et al. 1990) and Barcode of Life Database (BOLD) System (Ratnasingham and Hebert 2007). For the phylogenetic analysis, 40 of sequences from Gen Bank were used as references. A neighbor-joining phylogenetic tree was constructed using MEGA7 with Kimura-2 parameter models. Bootstraps of 1,000 were performed to determine the confidence levels to the nodes of the trees.

\section{RESULTS AND DISCUSSION}

A total of 25 beche-de-mers was obtained from local markets at Boalemo (17 local names), Pesawaran (5 local names), Surabaya (2 local names) and West Lombok (1 local name). All of DNA specimens (47) were successfully amplified using COI primers. The BLAST result was shown in Table 1 .

Table 1. COI similarity result of Indonesian beche-de-mers generated by BLAST and BOLD System analysis

\begin{tabular}{|c|c|c|c|c|c|}
\hline \multirow{2}{*}{ Local name } & \multirow{2}{*}{$\mathbf{N}$} & \multirow{2}{*}{$\begin{array}{l}\text { Collection } \\
\text { site }\end{array}$} & \multirow{2}{*}{ Species } & \multicolumn{2}{|c|}{ Similarity (\%) } \\
\hline & & & & BLAST & BOLD System \\
\hline Bintik (G) & 2 & Boalemo & Bohadschia argus & 98 & 98.98 \\
\hline Tangkiri (G) & 2 & Boalemo & Holothuria excellens & 98 & 99.54 \\
\hline Kunyit (G) & 1 & Boalemo & Holothuria fuscopunctata & 99 & 100.00 \\
\hline Cera duri $(\mathrm{G})$ & 1 & Boalemo & Pearsonothuria graeffei & 99 & 99.61 \\
\hline Cera hitam (G) & 2 & Boalemo & Holothuria atra & 99 & 99.85 \\
\hline Cera merah (G) & 2 & Boalemo & Holothuria edulis & 99 & 99.84 \\
\hline Blimbing (G) & 2 & Boalemo & Actinopyga echinites & 99 & 100.00 \\
\hline Polos $(\mathrm{G})$ & 2 & Boalemo & Bohadschia vitiensis & 99 & 99.85 \\
\hline $\operatorname{Kapok}(\mathrm{G})$ & 2 & Boalemo & Actinopyga lecanora & 99 & 99.23 \\
\hline $\operatorname{Kasur}(\mathrm{G})$ & 2 & Boalemo & Stichopus herrmanni/S. vastus/S. horrens/S. ocellatus* & 99 & 99.69 \\
\hline $\operatorname{Ular}(\mathrm{G})$ & 2 & Boalemo & Holothuria coluber & 99 & 99.54 \\
\hline Lolosong $(\mathrm{G})$ & 2 & Boalemo & Holothuria sp./ H. fuscocinerea** & 95 & 99.69 \\
\hline Duyung (G) & 1 & Boalemo & Bohadschia ocellata & 98 & 99.39 \\
\hline Gosok $(\mathrm{G})$ & 1 & Boalemo & Holothuria scabra & 99 & 99.37 \\
\hline Susu $(G)$ & 2 & Boalemo & Holothuria fuscogilva & 99 & 99.54 \\
\hline Alolo (G) & 2 & Boalemo & Bohadschia marmorata & 99 & 99.00 \\
\hline Pisang (G) & 2 & Boalemo & Holothuria fuscocinerea/ H. turriscelsa** & 99 & 99.39 \\
\hline Pasir (L) & 2 & Pesawaran & Holothuria scabra & 99 & 99.00 \\
\hline Kelapa (L) & 2 & Pesawaran & Actinopyga sp./A. miliaris & 96 & 99.85 \\
\hline Karang (L) & 2 & Pesawaran & Stichopus monotuberculatus/S. horrens & 99 & 99.85 \\
\hline Kasur (L) & 2 & Pesawaran & Stichopus monotuberculatus/S. horrens & 99 & 100.00 \\
\hline Olo-olo (L) & 2 & Pesawaran & Bohadschia marmorata & 99 & 99.85 \\
\hline Terung (S) & 2 & Surabaya & Phyrella sp. & 88 & NA \\
\hline Teripang (S) & 2 & Surabaya & Acaudina sp. & 87 & NA \\
\hline Gamat emas (LM) & 3 & W. Lombok & Stichopus horrens/S. monotuberculatus & 99 & 99.85 \\
\hline
\end{tabular}

Note: *: unresolved species according to BLAST and BOLD System analyses; **: species identification according to BOLD System analysis; NA: result not available 

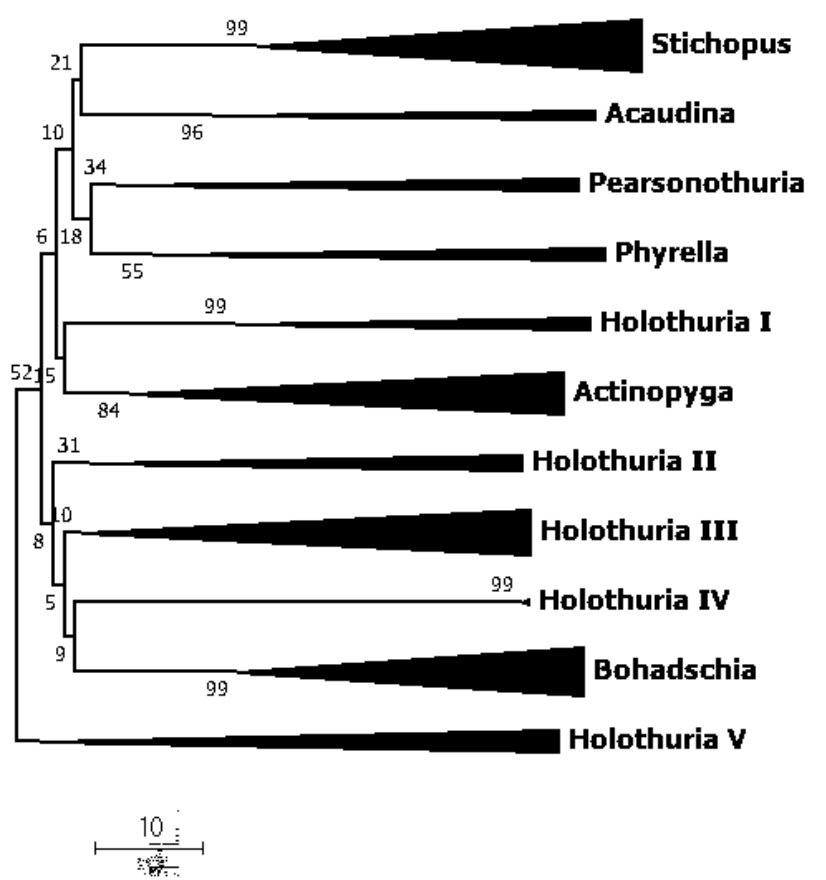

Figure 1. The phylogenetic tree of Indonesian beche-de-mers at the genus level. The tree was generated from the neighbor-joining analysis in the MEGA 7.0 software using 1000 replicates of the bootstrap test. Numbers shown next to the branches showed the bootstrap values.

The results showed that generally, the homology of beche-de-mer species in the database is between 95 to $100 \%$, except those of samples from Surabaya (terung and teripang) that only showed $87-88 \%$ similarity. Based on the results, the beche-de-mers can be divided into seven genera, i.e., Acaudina, Actinopyga, Bohadschia, Holothuria, Pearsonothuria, Phyrella and Stichopus. BLAST and BOLD System results for "lolosong" and "pisang" gave different results. "Lolosong" was similar to Holothuria sp. according to BLAST, or $H$. fuscocinerea according to BOLD System. "Pisang" was identified as Holothuria fuscocinerea (BLAST) and $H$. turriscelsa (BOLD System). Beche-de-mers produced from sea cucumber "karang", "kasur" and "gamat emas" were identified as Stichopus spp. with $99 \%$ of similarity to more than one species of Stichopus. Since the BLAST and BOLD System analyses have not been able to determine the exact species of the origin; therefore, further analysis using the phylogenetic tree was carried out.

The phylogenetic relationship between genus is shown in Figure 1. The results showed that most of the genera formed a monophyletic clade with a high number of bootstrap, except Holothuria which was formed into five clades (Holothuria I to V). Holothuria I was near Actinopyga clade, whereas Holothuria II-IV was close to Bohadschia clade. Holothuria $\mathrm{V}$ was distinct to the others.

\section{Actinopyga}

All Actinopyga was grouped into one clade in the phylogenetic tree (Figure 1) and was further classified into distinct sub-clades between species with high bootstrap values (Figure 2). Both specimens of "blimbing" from Boalemo were closely related to Actinopyga echinites, while those of "kapok" were similar to A. lecanora. "Kelapa" samples from Pesawaran were close to Actinopyga sp. according to BLAST analysis while BOLD System suggested A. miliaris (Table 1). Phylogenetic analysis of "kelapa" showed that this species was close to A. miliaris with a high number of bootstrap (100).

\section{Bohadschia}

Five beche-de-mers were grouped into Bohadschia genus (Figure 3). "Alolo" and "olo-olo" from Boalemo and Pesawaran, respectively, were both identified as Bohadschia marmorata, "polos" was B. vitensis, "bintik" and "duyung" were identified as B. argus and B. ocellata, respectively.

\section{Stichopus}

There are four local sea cucumbers classified as Stichopus namely "kasur" and "karang" (Pesawaran), "gamat emas" (West Lombok) and "kasur" (Boalemo). Even though the BLAST analysis showed a high similarity of each beche-de-mer to more than one species (Table 1), the phylogenetic tree was able to classify each of them into separated branches with high bootstrap values that confirmed their species level (Figure 4). "Kasur" and "karang" from Pesawaran have different local names. However, the phylogenetic analysis showed that both sea cucumbers were similar to Stichopus monotuberculatus; whereas, the other "kasur" from Boalemo, corresponded to S. herrmanni. Finally, "gamat emas" from West Lombok was identified as $S$. horrens.

\section{Holothuria}

According to the phylogenetic analysis (Figure 5), ten beche-de-mers were classified into the Holothuria group, leading this group as the largest group among others. However, species misidentification in this group often occurs. In this research, these beche-de-mers can be distinguished unambiguously, i.e., "susu" as $H$. fuscogilva, "kunyit" as $H$. fuscopunctata, "tangkiri" as $H$. excellens and "cera hitam" as $H$. atra (Figure 5). Since COI sequence data of $H$. turriscelsa was not available in the NCBI, therefore the phylogenetic similarity of "pisang" was close to $H$. fuscocinerea. In addition, "lolosong" was similar to H. fuscocinerea (BOLD System) with 99.69\%. However, the phylogenetic result, showed that this species was closer to Holothuria $\mathrm{sp}$. rather than $H$. fuscocinerea. Two specimens with different local names, "pasir" (Pesawaran) and "gosok" (Boalemo), were both identified as H. scabra.

In this study, Pearsonothuria, Phyrella, and Acaudina were only represented by one species for each genus (Figure 6), indicating their rarity in Indonesian waters. "Cera duri" from Boalemo was similar to Pearsonothuria graeffei, while samples from Surabaya, "terung" and "teripang", were identified as Phyrella sp. and Acaudina sp. respectively. 


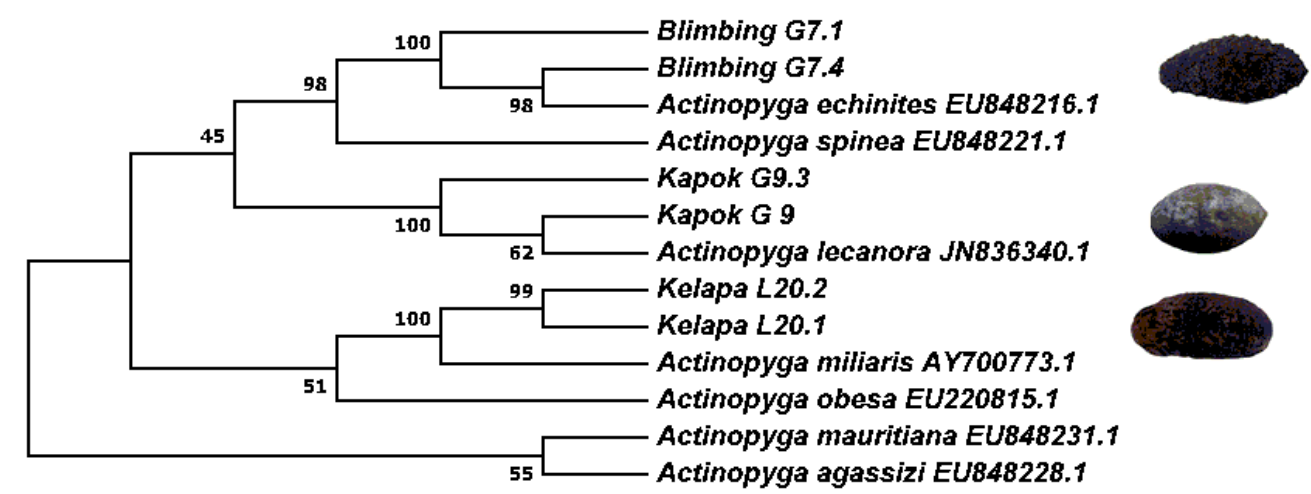

Figure 2. The phylogenetic tree of Actinopyga genus of Indonesian beche-de-mers. The tree was generated from the neighbor-joining analysis in the MEGA 7.0 software using 1000 replicates of the bootstrap test. Numbers shown next to the branches showed the bootstrap values. The samples were collected from Boalemo, Gorontalo (G) and Pesawaran, Lampung (L)

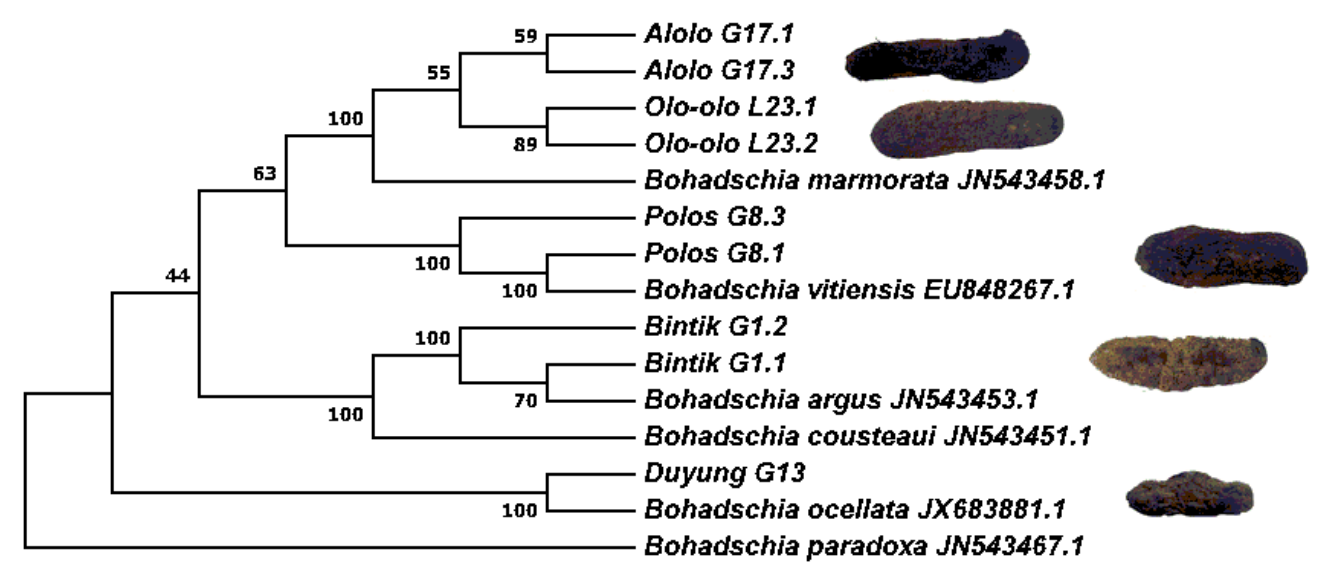

Figure 3. The phylogenetic tree of Bohadschia genus of Indonesian beche-de-mers. The tree was generated from the neighbor-joining analysis in the MEGA 7.0 software using 1000 replicates of the bootstrap test. Numbers shown next to the branches showed the bootstrap values. The samples collected from Boalemo, Gorontalo $(\mathrm{G})$ and Pesawaran, Lampung (L)

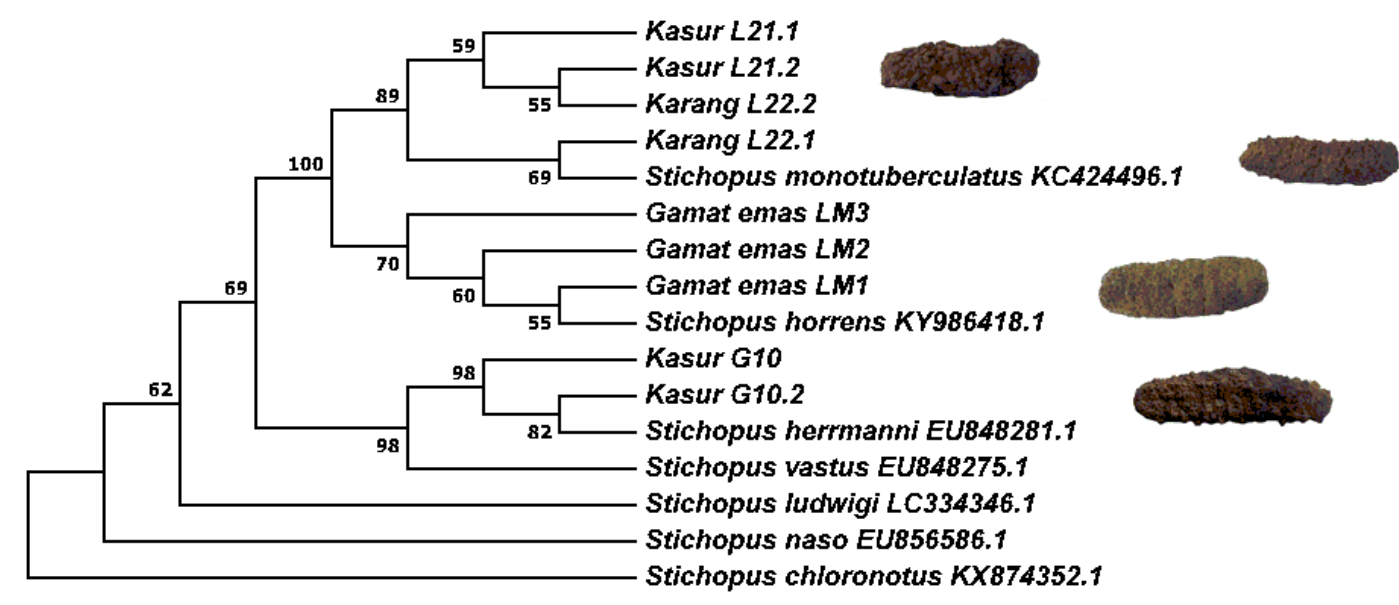

Figure 4. The phylogenetic tree of Stichopus genus of Indonesian beche-de-mers. The tree was generated from the neighbor-joining analysis in the MEGA 7.0 software using 1000 replicates of the bootstrap test. Numbers shown next to the branches showed the bootstrap values. The samples collected from Boalemo, Gorontalo (G), Pesawaran, Lampung (L)and West Lombok (LM) 


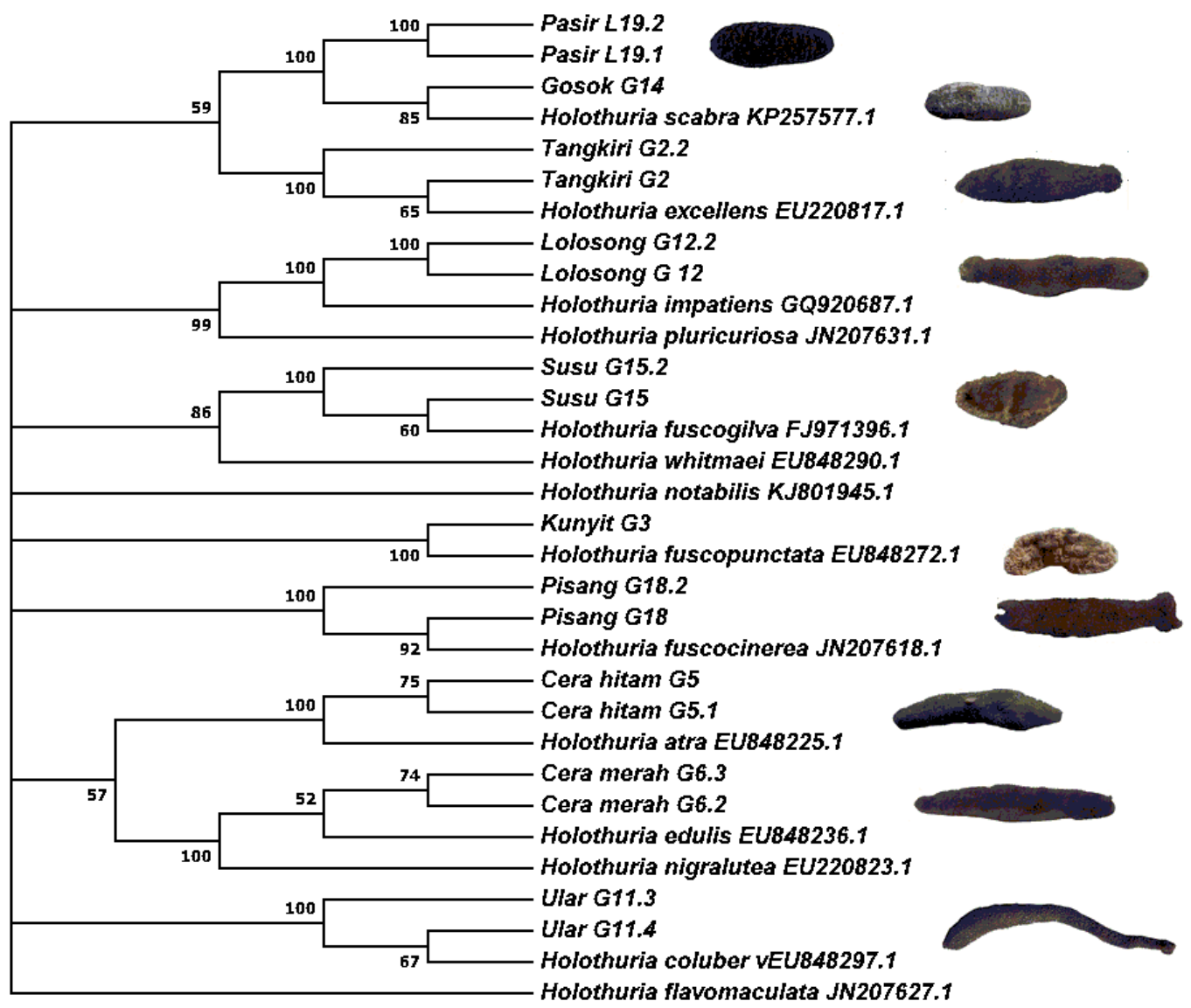

Figure 5. The phylogenetic tree of Holothuria genus of Indonesian beche-de-mers. The tree was generated from the neighbor-joining analysis in the MEGA 7.0 software using 1000 replicates of the bootstrap test. Numbers shown next to the branches showed the bootstrap values. The samples collected from Boalemo, Gorontalo (G) and Pesawaran, Lampung (L)

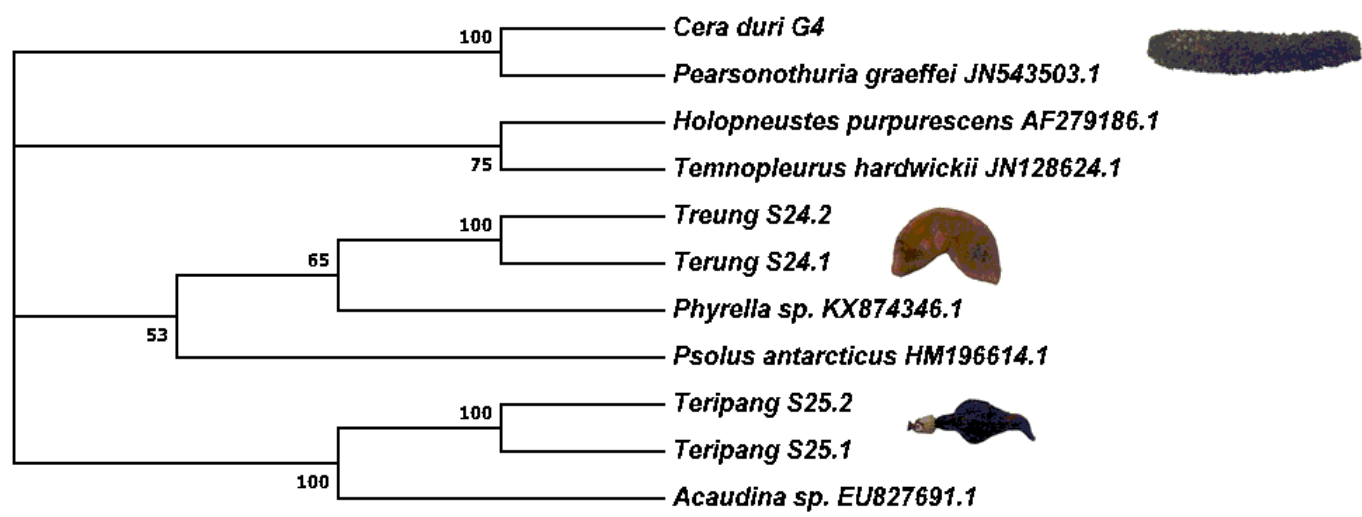

Figure 6. The phylogenetic tree of Pearsonothuria, Phyrella and Acaudina genera. The tree was generated from the neighbor-joining analysis in the MEGA 7.0 software using 1000 replicates of the bootstrap test. Numbers shown next to the branches showed the bootstrap values. The samples collected from Boalemo, Gorontalo (G) and Surabaya, East Java (S)

\section{Discussion}

The molecular methods have been widely used to identify various marine organisms and their processed products, including sea cucumbers, because of their specificity. In this study, we successfully identified 25 beche-de-mers from Boalemo, Pesawaran, Surabaya, and West Lombok with this particular technique. This molecular method compliments the morphological identification of commercial sea cucumbers from Indonesia that has been reported previously (Setyastuti and Purwati 2015). At the genus level, Holothuria group has more than one clades. This result was similar to the phylogenetic tree of commercial beche-de-mers by Uthicke et al. (2010), in which $H$. atra and $H$. edulis clades were next to 
Bohadschia, whereas $H$. coluber, H. fuscogilva, and $H$. fuscopunctata were grouped into different clades (Uthicke et al. 2010). They suggested that these results might indicate high variability of COI in the Holothuria genus. In addition, Holothuria consists of 18 subgenera that further divided into 160 species, while Actinopyga, Bohadschia, and Pearsonothuria have not been divided into subgenera (Honey-Escandón et al. 2012). The genetic distance among genus and species already discussed by Uthicke et al. (2010), therefore in this result we focused on the compatibility of the reported species identification from previous studies (Purwati 2005, 2006; Purwati et al. 2010; Setyastuti and Purwati 2015).

The identification of local beche-de-mers from Indonesia in Actinopyga genus was difficult. Purwati (2006) and Purwati et al. (2010) inconsistently reported that "kapuk" from West Lombok and "kapuk" from Karimunjawa were similar to A. lecanora, whereas in other papers, "kapuk" and "kapok" were similar to A. miliaris (Purwati 2005) or A. miliaris and A. echinites, respectively (Setyastuti and Purwati 2015). These ambiguities may be due to the different location of sample collection or visual similarity of this genus after being processed. Generally, the Actinopyga beche de mer has an oval shape, A. miliaris and $A$. lecanora have black and brown-black color with a size between $10-12 \mathrm{~cm}$, while A. echinites have a lighter color with a size between $8-15 \mathrm{~cm}$ (Purcell et al. 2012). Our results suggested that beche-de-mer with the local name of "kapok" from Boalemo was A. lecanora. Other local names of Actinopyga based on the morphological identification are shown in Table 2.

In the current study, slightly different local names in the Bohadschia group, "alolo" (Boalemo) and "olo-olo" (Pesawaran), showed similarity to B. marmorata. Additionaly, Purwati (2005) reported another local name of B. marmorata as "olok-olok". "Polos" and "bintik" from Boalemo were respectively identified as $B$. vitiensis and $B$. argus. These results were in agreement with those of previous studies (Setyastuti and Purwati 2015). However, the identification of "duyung" was different. "Duyung" was identified as Thelenota anax (amberfish) (Purwati 2005, 2006), while in this study the same species was identified as B. ocellata (= Holothuria ocellata). Our result was based on one specimen of "duyung" that were collected from different locations to that of the previous report. Therefore more studies need to be performed to secure the species identity of "duyung". According to the IUCN Red List of Threatened Species, generally, the conservation status of Bohadschia members is secure. B. argus has a stable population and has been categorized as least concern (Conand et al. 2013) while B. marmorata (Conand and Purcell 2013) has a decreasing population and has been classified as data deficient. The conservation status of $B$. vitiensis and B. ocellata have not been listed yet.

In some Indonesian regions, all Stichopus labeled as "gamat" (Setyastuti and Purwati 2015), regardless of species. Identification of Stichopus is often mistaken between $S$. horrens, S. monotuberculatus, S. quadrifasciatus and $S$. naso (Purcell et al. 2012) due to their similar appearances. A thorough and careful morphological identification is crucial to differentiate these four species (Massin 1999). In this study, the BLAST and BOLD System analysis for Stichopus group showed that there were more than one species that have high similarities (Table 1). Further analysis using a phylogenetic tree (Figure 4) separated $S$. horrens, S. herrmanni, and S. monotuberculatus. This is in agreement with the previous study by Uthicke et al. (2010) that found that the phylogenetic tree of COI sequences could be used to differentiate Stichopus because of their distinct clades and high bootstrap values among species. The conservation status of $S$. herrmanni is already vulnerable, while $S$. monotuberculatus and $S$. horrens are data deficient (Conand et al. 2013).

Table 2. The local name comparison of Indonesian beche-de-mers

\begin{tabular}{|c|c|c|c|}
\hline Species & $\begin{array}{c}\begin{array}{c}\text { Present } \\
\text { study }\end{array} \\
\end{array}$ & Setyastuti and Purwati (2015) & Common name \\
\hline Acaudina sp. & Teripang & - & - \\
\hline Actinopyga echinites & Blimbing & Kunyit, ladu-ladu, kapok, kapuk, billala, bilado, kassi & Deepwater redfish \\
\hline Actinopyga lecanora & Kapok & Batu, balibi, hitam & Stonefish \\
\hline Actinopyga miliaris & Kelapa & Kapok, kapuk, lotong, gamet, sepatu, hitam & Blackfish \\
\hline Bohadschia argus & Bintik & Ular mata, gamat bati, bintik, cempedak, patola & Leopardfish \\
\hline Bohadschia marmorata & Alolo, olo-olo & Kawasa, olok-olok, getah putih, pulut, benang, krido polos & Chalky cucumber \\
\hline Bohadschia vitiensis & Polos & Olok-olok, gatta, gama, polos & Brown sandfish \\
\hline Bohadschia ocellata & Duyung & Kacang goreng & - \\
\hline Holothuria atra & Cera hitam & Lakling hitam, coklat, hitam, dara, keling, cera & Lollyfish \\
\hline Holothuria coluber & Ular & Taikokong, talengko & Snakefish \\
\hline Holothuria edulis & Cera merah & Dada, cera, perut, lakling merah, takling, batu keling & Pinkfish \\
\hline Holothuria excellens & Tangkiri & Hitam & - \\
\hline Holothuria fuscocinerea & Pisang & Coklat, lakling coklat & - \\
\hline Holothuria fuscogilva & Susu & Susu putih, bissawa & White teatfish \\
\hline Holothuria fuscopunctata & Kunyit & Susu putih, kuning, kunyit & Elephant trunkfish \\
\hline Holothuria sp. & Lolosong & Pulut & Bottleneck sea cucumber \\
\hline Holothuria scabra & Gosok, pasir & Gosok, pasir, buang kulit, putih, kamboa & Sandfish \\
\hline Pearsonothuria graeffei & Cera duri & Bintik merah, gombyok, sutra, cera duri, gemuk, bati, donga & Blackspotted sea cucumber \\
\hline Phyrella sp. & Terung & - & - \\
\hline Stichopus herrmanni & Kasur & Gamet emas, gamet kacang, taikongkong & Curryfish \\
\hline Stichopus horrens & Gamat emas & Kacang goreng, taikongkong, kacang, susu, rengget & Dragonfish \\
\hline Stichopus monotuberculatus & Karang, kasur & Gamet pace & Dragonfish \\
\hline
\end{tabular}


Misidentification of Holothuria group is also common in Indonesia such as for $H$. fuscogilva, $H$. fuscopunctata, $H$. atra and H. excellens (Setyastuti and Purwati 2015). In this study, these beche-de-mers can be distinguished clearly. $H$. scabra was easily identified, despite its various local names. This sea cucumber is popular in Indonesia regions and is known as "pasir", "gosok", "buang kulit", "putih" and "kamboa" (Setyastuti and Purwati 2015). The lack of sequence of $H$. turriscelsa in the NCBI resulted "pisang" was identified as $H$. fuscocinerea in this phylogenetic analysis. However, the results may be different if both $H$. fuscocinerea and $H$. turriscelsa sequences were compared. The conservation status of most of the Holothuria members has not been evaluated. Some other Holothuria is data deficient and least concern. The status of $H$. scabra and $H$. fuscogilva, is endangered and vulnerable, respectively (Conand et al. 2013; Hamel et al. 2013).

"Teripang" and "terung" from Surabaya are traded locally, either for immediate consumption or as raw material for crackers. The identification of "teripang" in this study showed similarity to Acaudina sp. These results were similar to those of Amin and co-workers (2016) who identified the species using morphology and molecular identifications (Amin et al. 2016). In addition, the identification of $P$. graeffei is consistent with local name reported by Setyastuti and Purwati (2015). Others region called P. graeffei as "bantun", "donga", "karang" or "jepun" (West Lombok) and "gamat gombyok" (Karimunjawa) (Purwati 2006; Purwati et al. 2010).

To conclude, the identification of Indonesian beche-demers using molecular method could provide additional data and support for the identification of the local sea cucumbers to avoid mislabeling. Correct and reliable identification is important for the record of beche-de-mers trade in Indonesia and further conservation management as some of them are vulnerable and endangered. Collection of more samples from extended regions of Indonesia will be necessary as different location have different names of beche-de-mers.

\section{ACKNOWLEDGMENTS}

The study was funded by INSINAS grand No. 5/INS2/PPK/E4/2018 from the Indonesian Ministry of Research, Technology, and Higher Education through the Indonesian Institute of Sciences flagship.

\section{REFERENCES}

Afrely RW, Rosyidi MI, Fajariyah S. 2015. The diversity of Holothurioidea in the intertidal zone of the Pancur Shore of the Alas Purwo National Park. J Ilmu Dasar 16 (1): 23-28.

Altschul SF, Gish W, Miller W, Myers EW, Lipman DJ. 1990. Basic local alignment search tool. J Mol Biol 215 (3): 403-410.
Amin MHF, Pidada IBR, Sugiharto, Widyatmoko JN, Irawan B. 2016. Sea cucumber species identification of family Caudinidae from Surabaya based on morphological and mitochondrial DNA evidence. AIP Conference Proceedings 1718: 030001. DOI: 10.1063/1.4943311.

Arndt A, Marquez C, Lambert P, Smith MJ. 1996. Molecular phylogeny of Eastern Pacific sea cucumbers (Echinodermata: Holothuroidea) based on mitochondrial DNA sequence. Mol Phylogenet Evol 6 (3): 425-437.

Choo P-S. 2008. Population status, fisheries and trade of sea cucumbers in Asia. Sea cucumbers. A global review of fisheries and trade. FAO Fisheries and Aquaculture Technical Paper No. 516. Food and Agriculture Organization, Rome.

Conand C, Purcell S, Gamboa R. 2013. The IUCN red list of threatened species 2013. www.iucnredlist.org

Conand C, Purcell SW. 2013. The IUCN red list of threatened species 2013. www.iucnredlist.org

Di Pinto A, Marchetti P, Mottola A, Bozzo G, Bonerba E, Ceci E, Bottaro M, Tantillo G. 2015. Species identification in fish fillet products using DNA barcoding. Fisher Res 170: 9-13.

Fernandes TJR, Silva CR, Costa J, Oliveira MBPP, Mafra I. 2017. High resolution melting analysis of a COI mini-barcode as a new approach for Penaeidae shrimp species discrimination. Food Contr 82: 8-17.

Hamel J-F, Conand C, Pawson DL, Mercier A. 2001. The sea cucumber Holothuria scabra (Holothuroidea: Echinodermata): Its biology and exploitation as beche-de-mer. Adv Mar Biol 41: 129-223.

Hamel J-F, Mercier A, Conand C, Purcell SW, Toral-Granda T-G, Gamboa R. 2013. The IUCN red list of threatened species 2013. www.iucnredlist.org

Honey-EscandÓN M, Laguarda-Figueras A, SolÍS-MarÍN FA. 2012. Molecular phylogeny of the subgenus Holothuria (Selenkothuria) Deichmann, 1958 (Holothuroidea: Aspidochirotida). Zool J Linn Soc 165 (1): 109-120.

Kumar S, Stecher G, Tamura K. 2016. MEGA7: Molecular evolutionary genetics analysis version 7.0 for bigger datasets. Mol Biol Evol 33 (7): 1870-1874.

Madduppa H, Subhan B, Anggraini NP, Fadillah R, Tarman K. 2017. DNA barcoding reveals vulnerable and not evaluated species of sea cucumbers (Holothuroidea and Stichopodidae) from Kepulauan Seribu reefs, Indonesia. Biodiversitas 18 (3): 893-898.

Massin C. 1999. Reef-dwelling Holothuroidea (Echinodermata) of the Spermonde archipelago (south-west Sulawesi, Indonesia). Zool Verh Leiden 329 (30): 1-144.

Md-Zain BM, Abid-Kamal SNA, Aifat NR, Abdul-Latiff MAB, MohdHashim A, Ampeng A, Yaakop S, Samat A. 2018. Molecular identification of shark fins in Malaysian Borneo's local markets. Biodiversitas 19 (3): 1035-1043.

Peres B, Barlet N, Loiseau G, Montet D. 2007. Review of the current methods of analytical traceability allowing determination of the origin of foodstuffs. Food Contr 18: 228-235.

Purcell SW, Samyn Y, Conand C. 2012. Commercially important sea cucumbers of the world. FAO Species Catalogue for Fishery Purposes. No. 6. Food and Agriculture Organization, Rome.

Purwati P. 2005. Indonesian trepang: species composition and historical black-ground of the fisheries. Oseana 30 (2): 11-18. [Indonesian]

Purwati P. 2006. Souvenir from West Lombok, eastern Indonesia. SPC Beche-de-mer Inf Bull 23: 26-28.

Purwati P, Hartati R, Widianingsih. 2010. Eighteen sea cucumber species fished in Karimunjawa Islands, Java Sea. Mar Res Indonesia 35 (2): 23-30.

Rasmussen RS, Morrissey MT. 2008. DNA-based methods for the identification of commercial fish and seafood species. Compr Rev Food Sci Food Saf 7 (3): 280-295.

Setyastuti A, Purwati P. 2015. Species list of Indonesian trepang. SPC Beche-de-mer Inf Bull 35:19-25.

Supono, Lane DJ, Susetiono. 2014. Echinoderm fauna of the Lembeh Strait, North Sulawesi: inventory and distribution review. Mar Res Indonesia 39 (2): 51-61.

Uthicke S, Byrne M, Conand C. 2010. Genetic barcoding of commercial bêche-de-mer species (Echinodermata: Holothuroidea). Mol Ecol Res 10 (4): 634-646. 